\title{
Gambaran kadar asam urat pada pasien sindrom koroner akut di RSUP Prof. Dr. R. D. Kandou Manado periode Januari-Desember 2015
}

\author{
${ }^{1}$ Annisaa Syahfitri \\ ${ }^{2}$ Victor Joseph \\ ${ }^{2}$ Starry H. Rampengan
}

\author{
${ }^{1}$ Kandidat Skripsi Fakultas Kedokteran Universitas Sam Ratulangi Manado \\ ${ }^{2}$ Bagian Kardiologi Fakultas Kedokteran Universitas Sam Ratulangi Manado \\ Email: annisaasyah@gmail.com
}

\begin{abstract}
Acute coronary syndrome (ACS) is the term for symptoms due to disorder of blood flow inside the coronary arteries. ACS consists of unstable angina pectoris (UAP), non-ST-segment elevation myocardial infarction (NSTEMI), and ST-segment elevation myocardial infarction (STEMI). One predisposition factor of ACS that is still debated is uric acid. Its role in cardiovascular diseases is assumed due to endothelial disruption caused by elevated serum uric acid. This study was aimed to obtain the profile of uric acid serum in ACS patients at Prof. Dr. R. D. Kandou hospital Manado from January to December 2015. This was a retrospective study with a descriptive observational method using medical record of Prof Dr. R. D. Kandou Hospital Manado. The results showed that there were 97 patients with ACS, including 43 (44.33\%) patients with NSTEMI, 43 (44.33\%) patients with UAP, and $11(11.34 \%)$ patients with STEMI. Males were more common than females. Most patient were aged 55-65 years old. Elevated serum uric acid was found in 52\% of patients, generally in males and NSTEMI cases. More than half of the patients had history of elevated serum uric acid. The most risk factor in the cases were hypertension and smoking.
\end{abstract}

Keywords: description, uric acid, acute coronary syndrome

\begin{abstract}
Abstrak: Sindrom koroner akut (SKA) merupakan sekelompok gejala akibat gangguan aliran darah pada arteri koroner. SKA terdiri dari unstable angina pectoris (UAP), infark miokard tanpa elevasi ST (NSTEMI), dan infark miokard dengan elevasi ST (STEMI). Salah satu faktor predisposisi SKA yang hingga kini masih diperdebatkan ialah asam urat. Diduga peran asam urat terhadap penyakit kardiovaskular terletak pada gangguan endotel pembuluh darah yang ditimbulkannya. Penelitian ini bertujuan untuk mengetahui gambaran kadar asam urat pada pasien SKA di RSUP Prof. Dr. R. D. Kandou Manado selama periode JanuariDesember 2015. Jenis penelitian ialah retrospektif dengan metode observasional-deskriptif yang dilaksanakan di Bagian Rekam Medik RSUP Prof. Dr. R. D. Kandou Manado. Hasil penelitian mendapatkan 97 pasien SKA dengan data lengkap, diantaranya 43 kasus $(44,33 \%)$ NSTEMI, 43 kasus $(44,33 \%)$ UAP, dan 11 kasus (11,34\%) STEMI. Pasien terbanyak terdapat pada laki-laki dan kelompok usia 55-65 tahun. Peningkatan kadar asam urat dijumpai pada $52 \%$ pasien, umumnya pada laki-laki dan kasus NSTEMI. Umumnya pasien juga memiliki riwayat asam urat. Faktor risiko terbanyak yang dimiliki ialah hipertensi dan merokok.
\end{abstract}

Kata kunci: deskripsi, asam urat, sindrom koroner akut

Penyakit jantung merupakan salah satu penyebab utama kematian secara global. Pada tahun 2013, penyakit jantung masih menduduki peringkat pertama dari 15 penyebab kematian terbanyak di dunia. ${ }^{1}$ Menurut WHO, pada tahun 2012 sekitar 
17,5 juta jiwa meninggal akibat penyakit jantung, atau sekitar $31 \%$ dari total penyebab kematian di dunia, dan $>75 \%$ diantaranya merupakan penduduk di negara berkembang. ${ }^{2}$ Serangan jantung yang terjadi umumnya dikarenakan gangguan aliran darah pada arteri koroner yang disebut penyakit jantung koroner (PJK). Diperkirakan pada tahun 2020, PJK akan menjadi penyebab utama yaitu sebesar $36 \%$ dari seluruh kematian. PJK sering bermanifestasi sebagai sindroma koroner akut (SKA). ${ }^{3}$ Di Indonesia, pada beberapa wilayah peningkatan penderita SKA cukup bermakna. Pada penelitian yang telah dilakukan di RSUP Prof. Dr. R. D. Kandou Manado, didapatkan 55 kasus SKA pada tahun 2006, 104 kasus pada tahun 2007, 166 kasus pada tahun 2008, 251 kasus pada tahun 2009, dan 354 kasus pada tahun $2010 .^{4}$ SKA merupakan sekelompok gejala yang berhubungan dengan pembuluh darah koroner jantung, terdiri dari unstable angina pectoris (UAP), non ST elevated myocardial infarction (NSTEMI), dan ST elevated myocardial infarction (STEMI). ${ }^{5}$

Berbagai faktor dinilai berkaitan dengan kejadian SKA, salah satu faktor predisposisi yang sampai saat ini masih diperdebatkan tentang pengaruhnya pada SKA, yaitu kadar asam urat. Prevalensi hiperurisemia di Indonesia yaitu sebesar $18 \%$ dengan angka yang bervariasi di setiap daerah. ${ }^{6}$ Prevalensi hiperurisemia di Bali pada tahun 2009 ialah 12,22\% pada usia 13-85 tahun, pada laki-laki $15 \%$ dan pada perempuan $6,7 \%{ }^{7}$ Di Sulawesi Utara angka hiperurisemia belum diketahui. Khusus di Minahasa diperoleh angka kejadian hiperurisemia pada usia dewasa muda yakni $34,30 \%$, pada laki-laki $46,58 \%$ dan pada perempuan $23,31 \%{ }^{7}$ Pada remaja di Minahasa didapatkan dari 54 siswa obes diperoleh 8 orang di antaranya mengalami hiperurisemia $(14,82 \%){ }^{8}$

Menurut penelitian oleh Torry et al. ${ }^{4}$ ditemukan sekitar $33,3 \%$ pasien dengan SKA yang juga mengalami hiperurisemia. ${ }^{4}$ Kadar asam urat yang tinggi juga berkaitan dengan sindroma metabolik dan risiko terjadinya penyakit kardiovaskular. Hiper- urisemia ditemukan sekitar $39 \%$ dari seluruh kematian akibat penyakit kardiovaskular. ${ }^{9}$ Beberapa penelitian menyebutkan peran asam urat dalam menyebabkan penyakit kardiovaskular terletak pada jalur xanthine oxidase, sehingga saat terjadi hiperurisemia dapat berakibat kerusakan endotel pembuluh darah.,10 Begitu juga sebaliknya, penyakit yang berhubungan dengan kardiovaskular dapat menyebabkan timbulnya hiperurisemia sebagai penanda bahwa telah terjadi proses iskemik pada jantung. ${ }^{5,11}$ Berdasarkan data yang telah disebutkan, penulis tertarik untuk mengetahui gambaran kadar asam urat pada penderita penyakit kardiovaskular, dalam hal ini pasien dengan SKA.

\section{METODE PENELITIAN}

Jenis penelitian ini ialah deskriptif retrospektif dengan menggunakan data rekam medis pasien SKA di RSUP Prof. Dr. R. D. Kandou selama bulan Januari Desember 2015. Pemilihan sampel penelitian menggunakan consecutive sampling method. Sebanyak 97 pasien yang menjadi sampel ialah pasien dengan data lengkap termasuk hasil laboratorium asam urat. Sampel kadar asam urat yang digunakan dalam tes laboratorium ialah spesimen darah, dengan nilai normal untuk laki-laki 2-6,5 mg/dL dan perempuan 2-5,7 $\mathrm{mg} / \mathrm{dL}$. Data dianalisis dan disajikan dalam bentuk tabel, diagram, dan tulisan.

\section{HASIL PENELITIAN}

Total terdapat 97 sampel terdiri dari 69 orang $(71,13 \%)$ berjenis kelamin laki-laki dan sisanya sebanyak 28 orang $(28,87 \%)$ berjenis kelamin perempuan (Gambar 1).

\section{Distribusi berdasarkan jenis SKA dan jenis kelamin}

Terdapat 32 laki-laki $(46,4 \%)$ dan 11 perempuan $(39,3 \%)$ yang menderita NSTEMI dengan jumlah keseluruhan 43 orang. Penderita STEMI berjumlah 11 orang $(15,9 \%)$ yang semuanya berjenis kelamin laki-laki. Penderita UAP berjumlah 43 orang; 26 orang $(37,7 \%)$ berjenis kelamin laki-laki dan sisanya 17 
orang $(60,7 \%)$ berjenis kelamin perempuan (Tabel 1).

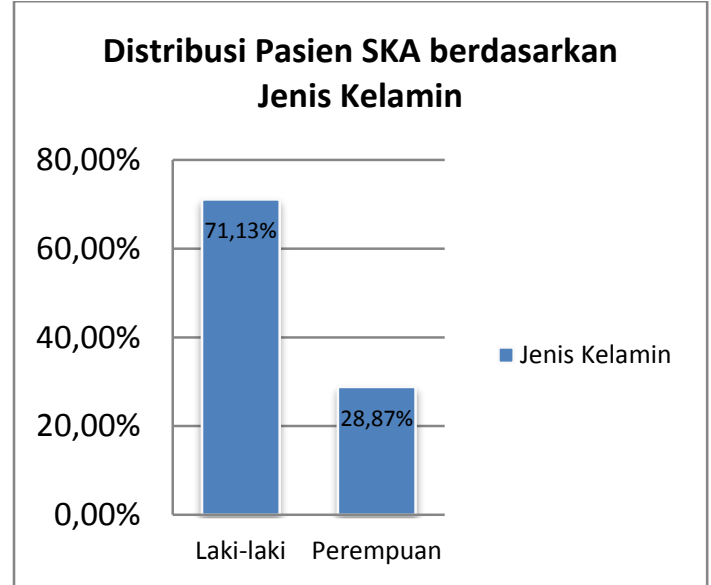

Gambar 1. Distribusi pasien SKA berdasarkan jenis kelamin

Tabel 1. Distribusi masing-masing jenis SKA berdasarkan jenis kelamin

\begin{tabular}{ccccc}
\hline \multirow{2}{*}{ Jenis } & \multicolumn{2}{c}{ Laki-Laki } & \multicolumn{2}{c}{ Perempuan } \\
\cline { 2 - 5 } SKA & $\mathrm{n}$ & \multirow{2}{*}{$(\%)$} & $\mathrm{n}$ & $(\%)$ \\
& $(69)$ & & $(28)$ & \\
\hline NSTEMI & 32 & 46,4 & 11 & 39,3 \\
STEMI & 11 & 15,9 & 0 & 0 \\
UAP & 26 & 37,7 & 17 & 60,7 \\
Total & 69 & 100 & 28 & 100 \\
\hline
\end{tabular}

\section{Karakteristik dasar}

Jumlah penderita UAP yang berjenis kelamin laki-laki sebanyak 26 orang, sedangkan untuk penderita NSTEMI dan STEMI masing-masing 32 orang dan 11 orang. Pasien berjenis kelamin perempuan yang menderita UAP sebanyak 17 orang, sedangkan NSTEMI 11 orang; tidak ada pasien STEMI yang berjenis kelamin perempuan (Tabel 2).

Berdasarkan distribusi usia penderita, terdapat 3 orang yang termasuk dalam kelompok usia <35 tahun; 29 orang termasuk dalam kelompok usia 36-55 tahun; 33 orang termasuk dalam kelompok usia 56-65 tahun; dan 32 orang yang termasuk dalam kelompok usia $>65$ tahun.
Dari keseluruhan data didapatkan sebanyak 68 orang dengan faktor risiko hipertensi; 28 orang dengan faktor risiko DM; 44 orang dengan faktor risiko kolesterol tinggi; 42 orang dengan riwayat asam urat tinggi; 46 orang dengan faktor risiko adanya riwayat penyakit jantung; 44 orang dengan faktor risiko merokok; dan 64 orang memiliki faktor risiko kombinasi (Tabel 2).

\section{Distribusi kadar asam urat}

Berdasarkan data yang diperoleh, kadar asam urat meningkat pada $52 \%$ pasien SKA; $48 \%$ memiliki kadar asam urat normal.

\section{Distribusi kadar asam urat berdasarkan jenis kelamin}

Berdasarkan jenis kelamin, terdapat 37 $(53,6 \%)$ dari 69 laki-laki penderita SKA yang memiliki nilai kadar asam urat tinggi. Terdapat $13(46,4 \%)$ dari total 28 orang perempuan yang memiliki nilai kadar asam urat tinggi (Tabel 3).

\section{Distribusi kadar asam urat berdasarkan jenis SKA}

Berdasarkan Tabel 4, pasien dengan UAP berjenis kelamin laki-laki yang mengalami hiperurisemia sejumlah 12 orang, sedangkan untuk perempuan 8 orang. Pada penderita UAP yang memiliki kadar asam urat normal untuk laki-laki sejumlah 14 orang dan perempuan 9 orang.

Pada pasien dengan NSTEMI, terdapat 19 laki-laki dan 5 perempuan yang memiliki kadar asam urat tinggi sedangkan yang memiliki kadar asam urat normal yaitu 13 laki-laki dan 6 perempuan. Untuk penderita STEMI yang semuanya berjenis kelamin laki-laki, didapatkan 6 orang yang memiliki kadar asam urat tinggi, dan 5 orang memiliki kadar asam urat normal. 
Tabel 2. Karakteristik dasar pasien SKA

\begin{tabular}{|c|c|c|c|c|}
\hline \multirow[b]{2}{*}{ Karakteristik } & \multicolumn{4}{|c|}{ Sindrom koroner akut } \\
\hline & $\begin{array}{l}\text { UAP } \\
(\mathrm{n}=43)\end{array}$ & $\begin{array}{c}\text { NSTEMI } \\
(\mathrm{n}=43)\end{array}$ & $\begin{array}{l}\text { STEMI } \\
(\mathrm{n}=11)\end{array}$ & $\begin{array}{l}\text { Jumlah } \\
(\mathrm{n}=97)\end{array}$ \\
\hline \multicolumn{5}{|l|}{ Jenis kelamin } \\
\hline - Laki-laki & $26(26,8 \%)$ & $32(33 \%)$ & $11(11,3 \%)$ & $69(71,1 \%)$ \\
\hline - Perempuan & $17(17,6 \%)$ & $11(11,3 \%)$ & $0(0 \%)$ & $28(28,9 \%)$ \\
\hline \multicolumn{5}{|l|}{ Usia (tahun) } \\
\hline$-<35$ & $1(1,03 \%)$ & $1(1,03 \%)$ & $1(1,03 \%)$ & $3(3,1 \%)$ \\
\hline$-35-55$ & $12(12,4 \%)$ & $12(12,4 \%)$ & $5(5,1 \%)$ & $29(29,9 \%)$ \\
\hline$-56-65$ & $14(14,4 \%)$ & $14(14,4 \%)$ & $5(5,1 \%)$ & $33(34 \%)$ \\
\hline$->65$ & $16(16,5 \%)$ & $16(16,5 \%)$ & $0(0 \%)$ & $32(33 \%)$ \\
\hline \multicolumn{5}{|c|}{$\begin{array}{l}\text { Faktor yang tidak dapat } \\
\text { dimodifikasi }\end{array}$} \\
\hline \multicolumn{5}{|c|}{$\begin{array}{l}\text { Faktor risiko yang dapat } \\
\text { dimodifikasi }\end{array}$} \\
\hline - Hipertensi & $27(27,8 \%)$ & $31(32 \%)$ & $10(10,3 \%)$ & $68(70,1 \%)$ \\
\hline - DM & $12(12,4 \%)$ & $12(12,4 \%)$ & $4(4,1 \%)$ & $28(28,9 \%)$ \\
\hline - Kolesterol & $19(19,6 \%)$ & $19(19,6 \%)$ & $6(6,2 \%)$ & $44(45,4 \%)$ \\
\hline - Merokok & $13(13,4 \%)$ & $28(28,9 \%)$ & $3(3,1 \%)$ & $44(45,4 \%)$ \\
\hline - Kombinasi & $27(27,8 \%)$ & $28(28,9 \%)$ & $9(9,3 \%)$ & $64(66 \%)$ \\
\hline - Tanpa FR & $3(3,1 \%)$ & $3(3,1 \%)$ & $0(0 \%)$ & $6(6,2 \%)$ \\
\hline \multicolumn{5}{|l|}{ Faktor Predisposisi } \\
\hline - Alkohol & $3(3,1 \%)$ & $5(5,1 \%)$ & $1(1,03 \%)$ & $9(9,3 \%)$ \\
\hline - Obesitas & $4(4,1 \%)$ & $4(4,1 \%)$ & $1(1,03 \%)$ & $9(9,3 \%)$ \\
\hline - Asam Urat & $18(18,6 \%)$ & $18(18,6 \%)$ & $6(6,2 \%)$ & $42(43,3 \%)$ \\
\hline
\end{tabular}

Tabel 3. Distribusi kadar asam urat pasien SKA berdasarkan jenis kelamin

\begin{tabular}{ccccc}
\hline \multirow{2}{*}{ Interpretasi } & \multicolumn{2}{c}{ Laki-Laki } & \multicolumn{2}{c}{ Perempuan } \\
\cline { 2 - 5 } & $\mathrm{n}$ & $(\%)$ & $\mathrm{n}$ & $(\%)$ \\
& $(69)$ & $(28)$ & \\
\hline Meningkat & 37 & 53,6 & 13 & 46,4 \\
Normal & 32 & 46,4 & 15 & 53,6 \\
\hline
\end{tabular}

Tabel 4. Distribusi kadar asam urat berdasarkan jenis SKA-nya

\begin{tabular}{lcccccccr}
\hline \multirow{2}{*}{$\begin{array}{c}\text { Kadar } \\
\text { asam urat }\end{array}$} & \multicolumn{7}{c}{ Sindrom koroner akut } \\
\cline { 2 - 8 } & $\mathrm{UAP}(\mathrm{n}=43)$ & \multicolumn{2}{c}{ NSTEMI $(\mathrm{n}=43)$} & \multicolumn{2}{c}{ STEMI $(\mathrm{n}=11)$} & \multicolumn{2}{c}{ Jumlah $(\mathrm{n}=97)$} \\
\cline { 2 - 8 } & $\mathrm{L}(\%)$ & $\mathrm{P}(\%)$ & $\mathrm{L}(\%)$ & $\mathrm{P}(\%)$ & $\mathrm{L}(\%)$ & $\mathrm{P}(\%)$ & $\mathrm{L}(\%)$ & $\mathrm{P}(\%)$ \\
\hline Meningkat & $12(12,4)$ & $8(8,3)$ & $19(19,6)$ & $5(5,1)$ & $6(6,2)$ & $0(0)$ & $37(38,1)$ & $13(13,4)$ \\
Normal & $14(14,4)$ & $9(9,3)$ & $13(13,4)$ & $6(6,2)$ & $5(5,1)$ & $0(0)$ & $32(33)$ & $15(15,5)$ \\
\hline
\end{tabular}

Distribusi kadar asam urat berdasarkan riwayat asam urat dahulu

Pasien SKA yang memiliki kadar asam urat meningkat menurut hasil pemeriksaan laboratorium, terbagi atas dua kelompok, yaitu yang memiliki riwayat asam urat meningkat dan yang tidak memiliki riwayat asam urat. Berdasarkan distribusi pada 
kelompok yang mengalami peningkatan kadar asam urat, kelompok yang dahulu memiliki riwayat asam urat meningkat sebanyak $56 \%$, dan yang tidak memiliki riwayat asam urat berjumlah $44 \%$. Kelompok yang memiliki kadar asam urat normal namun memiliki riwayat asam urat terdahulu sebanyak 29,79\% (Gambar 2).

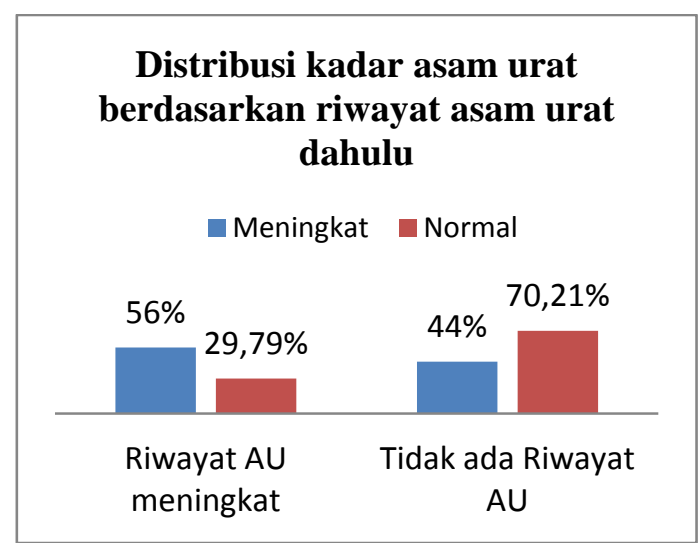

Gambar 2. Distribusi berdasarkan riwayat asam urat dahulu

\section{BAHASAN}

Dari keseluruhan jumlah sampel yang diambil, $71,13 \%$ diantaranya berjenis kelamin laki-laki dan sisanya sebanyak $28,87 \%$ berjenis kelamin perempuan. Hal ini sesuai dengan Pedoman Tatalaksana Sindrom Koroner Akut oleh PERKI yang menyebutkan bahwa risiko penyakit jantung sering terjadi pada laki-laki. ${ }^{12}$ Dalam penelitian lain juga menyebutkan sebagian besar pasien dengan penyakit kardiovaskular berjenis kelamin lakilaki. ${ }^{4,13,14}$ Hal ini dapat disebabkan oleh faktor risiko penyakit kardiovaskular yang umumnya terjadi pada laki-laki.

Menurut data penelitian, jenis SKA yang lebih banyak diderita ialah NSTEMI dan UAP namun berdasarkan hasil penelitian oleh Torry et $\mathrm{al}^{4}{ }^{4}$ jumlah penderita STEMI lebih banyak disbandingkan NSTEMI. ${ }^{4}$

Berdasarkan distribusi usia, penderita SKA terbanyak pada kelompok usia 56-65 tahun dan $>65$ tahun. Hal ini berkaitan dengan teori yang mengatakan bahwa SKA banyak diderita oleh lanjut usia. ${ }^{15}$ Lain halnya dengan penelitian oleh Torry et al. ${ }^{4}$ yang menyebutkan kelompok usia terbanyak penderita SKA ialah 46-55 tahun. Menurut Nielsen et al. ${ }^{14}$ usia terbanyak yang menderita SKA ialah 51-60 tahun. Perbedaan pendapat ini dapat disebabkan karena karakteristik pasien sampel yang berbeda-beda.

Data faktor risiko yang dimiliki pasien seperti usia, jenis kelamin, hipertensi, kolesterol, dan DM ternyata juga terdapat pada pasien dengan penyakit kardiovaskular seperti yang telah disebutkan dalam buku ajar. ${ }^{16}$ Faktor risiko yang tidak dapat dimodifikasi seperti menopause dini sebenarnya juga berpengaruh terhadap kejadian penyakit kardiovaskular, ${ }^{16}$ namun dikarenakan keterbatasan data selama penelitian sehingga tidak dapat dicantumkan dalam hasil penelitian.

Kebiasaan merokok juga tinggi pada penderita SKA. Merokok sering dikaitkan dengan penyakit kardiovaskular oleh karena perannya yang dapat menyebabkan disfungsi endotel dan penyakit kardiovaskular. ${ }^{17}$

Berdasarkan distribusi kadar asam urat sampel, yang memiliki kadar asam urat meningkat lebih banyak dibandingkan normal yaitu 52\%. Hal ini bertentangan dengan penelitian yang dilakukan oleh Torry et al. ${ }^{4}$ yang menyatakan bahwa kadar asam urat normal lebih banyak dibanding kadar asam urat meningkat. ${ }^{4}$ Berdasarkan jenis SKA, kadar asam urat lebih banyak meningkat pada penderita NSTEMI sedangkan kadar asam urat normal lebih banyak pada penderita UAP. Hal ini mungkin berkaitan dengan peningkatan asam urat lokal yang dapat terjadi akibat adanya iskemik, sehingga kadar asam uratnya ditemukan lebih banyak meningkat pada penderita NSTEMI. Peningkatan ini merupakan salah satu penanda terjadinya infark miokard dan mendukung teori hubungan non-kausal hiperurisemia dengan penyakit kardiovaskular, ${ }^{11}$ namun karena penelitian ini dilakukan dengan sampel yang sedikit, maka dianjurkan untuk melakukan penelitian lanjutan.

Peningkatan kadar asam urat dihubungkan dengan peningkatan risiko 
terjadinya penyakit kardiovaskular, tetapi di sisi lain dapat berperan juga sebagai antioksidan. $^{18,19}$ Meskipun peningkatan kadar asam urat berkaitan dengan penyakit kardiovaskular, namun terdapat faktorfaktor lain yang dapat memengaruhi mekanismenya.

Sintesis asam urat yang berasal dari degradasi purin akan membentuk hasil akhir yaitu asam urat. ${ }^{20}$ Produk sampingan hidrogen peroksida yang dihasilkan dari proses perubahan hipoxantin menjadi xantin selama pembentukan asam urat, telah lama dipertimbangkan sebagai senyawa anti-oksidan dan pro-oksidan. Sebagai antioksidan, asam urat menurunkan availabilitas dari peroksinitrit yang merupakan molekul pengikat radikal bebas, serta dapat berperan sebagai faktor protektif terhadap pembuluh darah. $^{21}$

Penelitian lain menyebutkan bahwa kaitan asam urat dengan penyakit kardiovaskular terletak pada perannya dalam menimbulkan stres oksidatif. ${ }^{22}$ Produk sampingan lain dari proses pembentukan asam urat yaitu XDH dan XO memiliki kemampuan memroduksi superoksida yang paling sering berkontribusi pada disfungsi endotel jantung. Superoksida mengganggu fungsi NO dan menyebabkan disfungsi endotel serta stres oksidatif. Disfungsi endotel yang terjadi dapat menjadi faktor risiko berbagai penyakit kardiovaskular. ${ }^{10}$ Disfungsi endotel yang terjadi dipercaya berperan penting dalam pembentukan aterosklerosis dan penumpukan formasi plak. $^{23}$

Jika ditinjau berdasarkan jenis kelamin, secara keseluruhan didapatkan 37 laki-laki $(53,6 \%)$ yang memiliki nilai kadar asam urat tinggi dari total 69 orang lakilaki penderita SKA sehingga dapat disimpulkan bahwa peningkatan kadar asam urat banyak dialami oleh laki-laki namun menurut Kawabe et al. ${ }^{24}$ peningkatan kadar asam urat lebih banyak ditemukan pada perempuan dengan SKA dan merupakan prediktor independen mortalitas pada perempuan. Menurut Zhao et al. ${ }^{25}$, peningkatan kadar asam urat lebih berisiko menyebabkan mortalitas pada laki- laki dibanding perempuan. Hal ini megindikasikan bahwa terdapat perbedaan peningkatan kadar asam urat berkaitan dengan jenis kelamin. Alasan peningkatan kadar asam urat lebih banyak ditemukan pada perempuan yaitu disebabkan adanya abnormalitas metabolik dan penyakit kardiovaskular yang berkembang pasca menopause saat hormon-hormon yang bersifat protektif terhadap pembuluh darah seperti estrogen berkurang karena proses penuaan. Beberapa penelitian lain menyebutkan bahwa peningkatan kadar asam urat yang ditemukan pada laki-laki biasanya di perantarai beberapa faktor risiko lain seperti hipertensi, dislipidemia, merokok dan riwayat penyakit jantung sebelumnya. ${ }^{11}$

Jika peningkatan kadar asam urat dihubungkan dengan faktor risiko yang dimiliki pasien, faktor risiko terbanyak ialah hipertensi. Sesuai dengan penelitian oleh Zohreh et al. ${ }^{22}$ peningkatan kadar asam urat juga umum ditemukan pada pasien dengan hipertensi. Asam urat dapat mengaktifkan sistem renin-angiotensin yang akan memicu terjadinya disfungsi endotel dan vasokonstriksi pembuluh darah sehingga menyebabkan hipertensi. ${ }^{26}$

Tingginya angka faktor risiko yang dimiliki pasien menunjukkan bahwa asam urat bukan merupakan satu-satunya faktor penyebab penyakit kardiovaskular. Sesuai dengan penelitian oleh Timoteo et al. $^{27}$ yang menyebutkan bahwa asam urat merupakan faktor independen mortalitas pasien SKA. $^{27}$

Beberapa penelitian menyebutkan mengenai adanya hubungan antara asam urat dan penyakit kardiovaskular, terutama SKA, namun tidak semua penelitian dapat menjelaskan dengan jelas peran asam urat dalam menyebabkan penyakit kardiovaskular. Bahkan dari beberapa penelitian yang telah dilakukan terdapat banyak perbedaan pendapat yang berkaitan dengan asam urat dan hubungannya dengan penyakit kardiovaskular. Hingga saat ini perbedaan pendapat ini masih sementara di diskusikan. ${ }^{28}$ 


\section{SIMPULAN}

Berdasarkan hasil penelitian terhadap 97 pasien sindrom koroner akut didapatkan kasus terbanyak ialah NSTEMI dan UAP. Pasien terbanyak terdapat pada laki-laki, kelompok usia 55-65 tahun, dan faktor risiko hipertensi dan merokok. Pasien yang memiliki kadar asam urat meningkat sebesar 52, umumnya pada laki-laki dan kasus NSTEMI. Umumnya pasien yang mengalami peningkatan kadar asam urat juga memiliki riwayat asam urat sebelumnya.

\section{SARAN}

Penelitian ini memiliki beberapa keterbatasan antara lain karena metode penelitian yang digunakan ialah retrospektif sehingga data yang diperoleh banyak dieksklusikan karena tidak lengkap, dan juga penelitian dilakukan dengan jumlah sampel dan periode yang terbatas.

Diharapkan penelitian selanjutnya dapat dilakukan dengan jumlah sampel yang lebih besar dan menggunakan desain penelitian analitik agar dapat mengetahui hubungan kadar asam urat dengan sindrom koroner akut (SKA).

\section{DAFTAR PUSTAKA}

1. Jiaquan Xu, Murphy SL, Kochanek KD, Bastian BA. Deaths: Final Data for 2013. Division of Vital Statistic. CDC. 2016;64;2

2. WHO. Fact sheet about cardiovascular disease. Online. [cited: August 2016]. Available

from: http://www.who.int/mediacentre/factsh eets/fs 317

3. Departemen Kesehatan RI. Buku Saku Pharmaceutical Care: Sindroma Koroner Akut, 2006

4. Torry S, Panda LA, Ongkowijaya J. Gambaran faktor risiko penderita sindrom koroner akut. eCl. 2014;2(1);1-8.

5. Murti R, Suryono N, Firdaus J. Hubungan kadar asam urat terhadap kejadian sindrom koroner akut Di RSD Dr. Soebandi Kabupaten Jember. Artikel Ilmiah Hasil Penelitian Mahasiswa. Jember: Universitas Jember; 2015.

6. Smith E, March L. Global prevalence of hyperuricemia: a systematic review of population-based epidemiological studies [abstract]. Arthritis Rheumatol. 2015;67.

7. Tilaar E, Kaligis S, Purwanto D. Gambaran kadar asam urat darah pada mahasiswa angkatan 2011 Fakultas Kedokteran Universitas Sam Ratulangi dengan indeks massa tubuh $18,5-22,9 \mathrm{~kg} / \mathrm{m}^{2}$. eBm. 2013;1(1);220-4.

8. Wurangian VGN, Kepel B, Manampiring AE. Gambaran asam urat pada remaja obes di Kabupaten Minahasa. eBm. 2014;2(1);1-5.

9. Oliveira EP, Burini RC. High plasma uric acid concentration: causes and consequences. Diabetology \& Metabolic Syndrome. 2012;4;12;1-7.

10. Gustafson D, Unwin R. The pathophysiology of hyperuricaemia and its possible relationship to cardiovascular disease, morbidity and mortality. BMC Nephrol. 2013;14(159);1-9.

11.Lin GM, Li YH, Zheng NC, Lai CP, Lin CL, Wang JH, et al. Serum uric acid as an independent predictor of mortality in high risk patients with obstructive coronary artery disease. J Cardiol. 2013;61;122-27.

12.Perhimpunan Dokter Spesialis Kardiovaskular Indonesia. Pedoman Tata Laksana Sindroma Koroner Akut, 2015.

13. Murad H, Dey R, Chowdhury MAI, Ullah HH, Rouf MA. Level of serum uric acid along with other demographic parameters in patients with acute coronary syndrome. Chattagram MaaO-Shishu Journal. 2014;13(2);55-8.

14. Nielsen HS, Pedersen CT, Finer N, Caterson ID, Gaal LV, James WPT, et al. Uric acid as a risk factor for cardiovascular disease and mortality in overweight/obese individuals. Plos One. 2013;8(3);1-9.

15.Jin M, Yang F, Yang I, Yin Y, Luo JJ, Wang $\mathbf{H}$, et al. Uric Acid, hyperuricemia and vascular diseases. Front Biosici. 2012;17;656-69.

16. Brown CT. Penyakit aterosklerotik koroner. In: Patofisiologi: Konsep Klinis Prosesproses Penyakit Volume 1 (6th ed). Jakarta: EGC. 2005;576-87.

17. Messner B, Bernhard D. Smoking and cardiovascular disease: mechanisms of endothelial dysfunction and early 
atherogenesis. ATVB AHA Journal. 2014;34;509-15.

18. Rodrigues SL, Baldo MP, Capingana DP, Magalhaes P, Dantas EM, Mollina MC, et al. Gender distribution of serum uric acid and cardiovascular risk factors: population based study. Arq Bras Cardiol. 2011;0;1-9.

19.Pasalic D. Marinkovic N, Turkovic LF. Uric acid as one of the important factors in multifactorial disorders facts and controversies. Biochemia Medica. 2012;22(1);63-75.

20. Rodwell VW. Metabolisme nukleotida purin dan pirimidin. In: Murray K, Granner DK, Rodwell VW, editor. Biokimia Harper (27th ed). Jakarta: EGC, 2013; p. 313-7.

21.Kang DH, Ha SK. Uric acid puzzle: Dual role as anti-oxidant and pro-oxidant. Electrolyte Blood Press. 2014;12;1-6.

22. Soltani Z, Rasheed K, Kapusta DR, Reisin E. Potential role of uric acid in metabolic syndrome, hypertension, kidney injury and cardiovascular diseases. Current Hypertension Reports. 2013;15(3);175-81.

23. Myrtha R. Patofisiologi sindrom koroner akut. CDK. 2012:39(4):261-4
24. Kawabe M, Sato A, Hoshi T, Sakai S, Hiraya D, Watabe D, et al. Gender differences in the association between serum uric acid and prognosis in patients with acute coronary syndrome. J Cardiol. 2016;67(2);170-6.

25.Zhao G. Huang L, Song M, Song Y. Baseline serum uric acid level as a predictor of cardiovascular disease related mortality and all-cause mortality: a meta-analysis of prospective studies. Atherosclerosis. 2013;231(1);61-8.

26. Umami HR. Hubungan antara peningkatan kadar asam urat darah dengan kejadian hipertensi di RSUD Sukoharjo [Skripsi]. Surakarta: UMS; 2015.

27. Timoteo AT, Lousinha A, Labandeiro J, Miranda F, Papoila AL, Oliveira JA, et al. Serum uric acid: a forgotten prognostic marker in acute coronary syndromes. Eur Heart J. 2013;2(1);4452.

28. Puddu P, Puddu GM, Cravero E, Vizioli L, Muscari A. The relationships among hyperuricemia, endothelial dysfunction, and cardiovascular diseases: molecular mechanisms and clinical implications. J Cardiol. 2012;59;235-42. 